\title{
EFFICACY AND SAFETY OF GROWING RODS IN THE TREATMENT OF SCOLIOSIS IN CHILDREN UNDER 10
}

\author{
EFICÁCIA E SEGURANCCA DE HASTES DE CRESCIMENTO NO TRATAMENTO DA ESCOLIOSE \\ EM CRIANÇAS MENORES DE 10
}

\author{
EFICACIA Y SEGURIDAD DE LAS BARRAS DE ALARGAMIENTO EN EL TRATAMIENTO DE \\ ESCOLIOSIS EN NIÑOS MENORES DE 10 AÑOS
}

Carlos Segundo Montero, ${ }^{1}$ David Meneses, ${ }^{1}$ Fernando Alvarado, ${ }^{1}$ Wilmer Godoy, ${ }^{1}$ Gabriel Alcalá, ${ }^{1}$ Carlos Martinez, ${ }^{1}$ Ricardo José Méndez ${ }^{1}$

1. Instituto Roosevelt, Cirugía de Columna, Bogotá, Colombia.

\begin{abstract}
Objective: To determine the efficacy and safety of growing rods in the treatment of scoliosis in children aged under 10 years. Methods: A retrospective review of medical records of patients under 10 with scoliosis, treated with growing rods from the period between 1997 and 2012. Results: We identified 35 patients treated with growing rods who met the selection criteria. The average age at the start of treatment was $5.9 \pm$ 2.3 years. Most of the patients (51.4\%) showed idiopathic etiology scoliosis. Pre-surgery and post-surgery radiographic change showed a $47.7 \%$ reduction in Cobb angle ( $\mathrm{p}>0.001)$. We identified 8 patients with some complication, the most prevalent being instrumentation failure (22.9\%). The only predicting factor for post-operative complications was the total number of lengthenings performed $(\mathrm{OR}=7.03$; $\mathrm{Cl}$ 95\% [1.1-45.4]; $p=0.040$ ). Conclusions: Treatment of scoliosis with growing rods in patients aged under 10 achieved a significant reduction in the magnitude of the deformity before final bone fusion. However, the rate of complications is rather high, therefore we recommend reducing the frequency of lengthenings to the minimum needed to maintain correction and longitudinal growth of the spine. Level of Evidence IV; Case series.
\end{abstract}

Keywords: Scoliosis; Prostheses and implants; Child; Spinal curvature.

\section{RESUMO}

Objetivo: Determinar a eficácia e segurança de hastes de crescimento no tratamento de escoliose em crianças menores de 10 anos. Métodos: Revisão retrospectiva de prontuários de pacientes menores de 10 anos com escoliose, tratados com hastes de crescimento entre 1997 e 2012. Resultados: Identificamos 35 pacientes, que foram tratados com hastes de crescimento, que satisfizeram os critérios de seleção. A idade média no início do tratamento foi de 5,9 9 2,3 anos. A maioria dos pacientes (51,4\%) apresentou escoliose de etiologia idiopática. A alteração radiográfica pré e pós-operatória mostra uma redução de 47,7\% do ângulo de Cobb (p>0,001). Foram identificados 8 pacientes com alguma complicação, sendo falha de instrumentação a mais prevalente (229\%). O único fator preditivo para complicações pós-operatórias foi o número total de alongamentos realizados (OR =7,03; IC95\% [1,1-45,4]; $p=0,040)$. Conclusão: 0 tratamento para escoliose em pacientes com menos de 10 anos com hastes de crescimento alcançou uma redução significativa na magnitude da deformidade antes da fusão óssea final. No entanto, a frequência de complicações é bastante alta e, para isso, recomendamos reduzir ao mínimo a frequência de alongamentos, a fim de manter a correção e o crescimento longitudinal da coluna. Nível de Evidência IV; Série de casos.

Descritores: Escoliose; Próteses e implantes; criança; Curvaturas da coluna vertebral.

\section{RESUMEN}

Objetivo: Determinar la eficacia y seguridad de las barras de alargamiento en el tratamiento de la escoliosis en niños menores de 10 años. Métodos: Revisión retrospectiva de registros médicos de pacientes menores de 10 años con escoliosis, tratados mediante barras de alargamiento entre 1997 y 2012. Resultados: Se identificaron 35 pacientes tratados con barras de alargamiento que satisfacían los criterios de selección. El promedio de edad al inicio del tratamiento fue de 5,9 \pm 2,3 años. La mayoría de los pacientes (51,4\%) tenían escoliosis de etiología idiopática. El cambio radiográfico prequirúrgico y postquirúrgico mostró reducción del 47,7\% en el ángulo de Cobb ( $p>0,001)$. Se identificaron 8 pacientes con alguna complicación, siendo el fallo del instrumental más prevalente (22,9\%). El único factor predictor de complicaciones postoperatorias fue el número total de alargamientos realizados $(O R=7,03 ; 1 C$ 95\% [1,1-45,4]; $p=0,040)$. Conclusiones: El tratamiento de la escoliosis con barras de alargamiento en pacientes menores de 10 años logró una reducción significativa de la magnitud de la deformidad antes de la fusión ósea definitiva. Sin embargo, la tasa de complicaciones es bastante alta, por lo cual se recomienda disminuir la frecuencia de alargamientos al mínimo necesario para mantener la corrección y el crecimiento longitudinal de la columna vertebral. Nivel de Evidencia IV; Serie de Casos.

Descriptores: Escoliosis; prótesis e implantes; Niño; Curvaturas de la columna vertebral. 


\section{INTRODUCTION}

The treatment of scoliosis in patients under 10 aims to reduce the magnitude and maintain the correction of the deformity while the longitudinal growth of the spine takes place, allowing expansion of the thorax and development of lung parenchyma. ${ }^{1}$

Four systems are currently used for surgical treatment of patients under 10 with scoliosis: single growing rods, dual growing rods, vertical expandable prosthetic titanium ribs (VEPTR), and magnet-controlled growing rods; ${ }^{1-5}$ currently, growing rods are the standard treatment, and are therefore the most widely used therapy worldwide., ${ }^{1,6}$

Harrington rods are considered the precursors of the lengthening methods available nowadays. ${ }^{7}$ In the late 70 s and early 80 s, these rods were used without vertebral fusion in patients with EPAT. They were inserted under the subcutaneous cellular tissue to produce stabilizing effects, rather like an "internal brace", which was complemented with an external postoperatory brace. ${ }^{7}$ The rods were periodically elongated upon finding an increase of 10 or more degrees in the deformity, which explains the unsatisfactory results of this treatment. ${ }^{7}$ In addition, the instrumented segments only achieved $84 \%$ of the expected longitudinal growth, which contravened the purpose of the treatment. $^{8}$

The lengthening systems available nowadays not only preserve the longitudinal growth of the spine; ${ }^{9}$ Swine models and EPAT patient follow-ups have shown that the distraction forces they exert accelerate apophysis growth in the axial skeleton, ${ }^{9-11}$ thereby achieving an increase in T1-S1 length that varies from 1 to 1.8 centimeters per year. ${ }^{12-14}$

Despite their efficacy in preserving the growth of the spine, one of the main disadvantages of growing rods are the complications related to instrumentation, or those associated with multiple extension procedures. ${ }^{14-18}$

The purpose of this study is to describe the efficacy and safety results of surgical treatment of scoliosis in children under 10 using growing rods, at a Colombian reference center.

\section{METHODS}

Our ethics committee and the institutional review board approved the research protocol for this study. The authors declare no conflicts of interest in the performance of this work. We carried out a retrospective study of a series of cases in which we reviewed the clinical history records of patients under 10 diagnosed with scoliosis, treated in the Roosevelt Children Orthopedics Institute (IOIR, its acronym in Spanish) from the period between 1997 and 2012.

We carried out a convenience sampling, including all scoliosis patients who received surgical treatment with elongating rods in the period studied, and excluded all patients diagnosed with syndromic scoliosis, and with incomplete records in their clinical history.

Patients who, after surgical treatment, presented a Cobb angle of over 40 degrees, those with curves of between 20 and 40 degrees, and those who showed a progression in the deformity of more than 5 degrees despite the use of a brace, were also excluded. Treatment was only applied in patients with skeletal immaturity, under a clinical and radiological evaluation (Risser sign $\leq 2$ ).

The following variables were recorded during the data collection: sex, age at the time of surgery, etiology of the scoliosis, number of rods inserted, preoperative and postoperative Cobb angle ${ }^{19}$, time between lengthenings, total number of lengthenings performed, surgery time, estimated bleeding, and rate of complications.

\section{Statistical Analysis}

For quantitative variables, the central tendency and dispersion measures were calculated; for categorical variables, proportions were calculated. Statistical differences between preoperative and postoperative Cobb angle were obtained through t-student test for related samples. The relation between the presence of complications and the possible predictor variables was assessed in univariate analysis using the t-student test for independent samples in continuous variables, and ji2 for dichotomous variables. The regression mode ${ }^{20}$ was built including those variables $p<0.250$ in the univariate analysis and in those significant variables within the model, the Odds Ratio (OR) is reported, with the corresponding 95\% confidence interval (Cl 95\%).

All statistical analyses were performed with IBM SPSS (Statistical Package for the Social Sciences) statistical software, version 2.0 (SPSS, Inc., Chicago, IL, USA).

\section{Ethical Considerations}

Given its observational design, this study has no ethical limitations regarding treatment indications; however, for the data gathering, we received the informed consent from patient's relatives. We also received approval from the Institutional ethics committee.

\section{RESULTS}

A total 721 cases of scoliosis in patients under 10 were reviewed. Of these, 35 (5\%) required surgical treatment with growing rods and met the selection criteria. Table 1 shows the characteristics of the sample. Table 2 summarizes the information on the surgical procedures performed.

The presurgical and postsurgical radiographic change showed a $47.7 \%$ reduction in the Cobb angle $\left(31.8^{\circ} \pm 14.6^{\circ}\right.$ difference), which was statistically significant ( $p<0.001$; t-student).

During the study period, 8 patients $(22.9 \%)$ showed some procedure-related complication; another 8 patients (22.9\%) showed instrumentation failures, and 2 cases (5.7\%) showed infection in the operated area which, it should be noted, was associated with instrumentation failure. Univariate analysis was performed to define which variables could be potential predictor factors of complications in our patient sample (Table 3).

Univariate analysis demonstrated that male gender, idiopathic and neuromuscular scoliosis diagnoses, preoperatory Cobb angle and the number of lengthenings performed were potential predictor factors of postoperatory complications $(p<0.05)$, and were therefore included in a bivariate logistic regression model. This model showed that for every two lengthenings performed on patients in the sample, the risk of complications increased by a factor of $7(\beta=1.951$; $\mathrm{OR}=7.03 ; \mathrm{Cl} 95 \%$ [1.1-45.4]; $p=0.040)$. For the other preselected variables, no statistical significance was reached.

Table 1. Study sample characteristics.

\begin{tabular}{c|c}
\hline Male gender & $20(57)$ \\
\hline Age at time of surgery* & $5.9 \pm 2.3$ years \\
\hline Infantile idiopathic scoliosis & $18(51.4)$ \\
\hline Congenital scoliosis & $11(31.4)$ \\
\hline Neuromuscular scoliosis & $6(17.1)$ \\
\hline Preoperatory Cobb angle ${ }^{*}$ & $66.7 \pm 14.4$ degrees \\
\hline Follow-up* & $27.0 \pm 15.7$ months \\
\hline
\end{tabular}

Results are shown in frequencies, and proportions for each group appear in parenthesis; * average \pm standard deviation.

Table 2. Surgical information

\begin{tabular}{c|c}
\hline Surgeries to place the system & 35 \\
\hline System composition & $2(6)$ \\
\hline One rod & $33(94)$ \\
\hline Two rods & $233.4 \pm 19.3$ \\
\hline Surgery time (min) ${ }^{*}$ & $129.9 \pm 13.4$ \\
\hline Intrasurgical bleeding (mL) & 106 \\
\hline Surgeries to elongate the system & $3[2-4]$ \\
\hline Lengthenings per patient† & $9.4 \pm 6.1$ \\
\hline Months between lengthenings ${ }^{*}$ & $118.2 \pm 10.1$ \\
\hline Surgery time (min)* & $45.0 \pm 42.4$ \\
\hline Intrasurgical bleeding (mL) &
\end{tabular}

Results are shown in frequencies and, proportions for each group appear in parenthesis; min: minutes; $\mathrm{mL}$ : milliliters: * average \pm standard deviation + median [interquartile range] 
Table 3. Univariate analysis of potential complication predictor factors.

\begin{tabular}{c|c|c|c|c|c}
\hline Variable & \multicolumn{2}{|c|}{$\begin{array}{c}\text { Patients with } \\
\text { complications } \\
\text { (n= 8) }\end{array}$} & \multicolumn{2}{|c|}{$\begin{array}{c}\text { Patients } \\
\text { without } \\
\text { complications } \\
\text { (n= 27) }\end{array}$} & p \\
\hline Males & 2 & $(25.0)$ & 18 & $(66.7)$ & 0.051 \\
\hline Two-rod fixation & 7 & $(87.5)$ & 26 & $(96.3)$ & NS \\
\hline Idiopathic scoliosis & 2 & $(25.0)$ & 16 & $(59.3)$ & 0.121 \\
\hline Neuropathic scoliosis & 3 & $(37.5)$ & 3 & $(11.1)$ & 0.117 \\
\hline Congenital scoliosis & 3 & $(37.5)$ & 8 & $(29.6)$ & NS \\
\hline Preoperatory Cobb angle* & 73.13 & \pm 13.26 & 64.85 & \pm 14.3 & 0.156 \\
\hline $\begin{array}{c}\text { Number of lengthenings } \\
\text { performedt }\end{array}$ & 4 & {$[3.25-5]$} & 3 & {$[2-4]$} & 0.016 \\
\hline
\end{tabular}

Results are shown in frequencies and, proportions are shown in parenthesis; * average \pm standard deviation $†$ median [interquartile range].

\section{DISCUSSION}

This study gathered, retrospectively, the results of the use of growing rods in the treatment of scoliosis patients aged under 10 , including idiopathic, congenital, and neuromuscular scoliosis.

In this study, we found a statistically significant reduction in the preoperative Cobb angle of $47.7 \%$ vs. the postoperative angle. This degree of correction is slightly lower than that reported in literature, ${ }^{14,21-23}$ which may be explained by the fact that the data was gathered from images prior to the final surgery, after which we would expect additional correction in most patients. $24,26,27$

In regards to the frequency of the lengthenings, our usual practice is to indicate them is to indicate them after six months; however, the median of the intervals between surgeries in this series was 8 months, which may possibly be due to logistic problems in the health system. Although the optimum interval between lengthenings is still unknown, and neither is it clear whether this interval should vary depending on the longitudinal growth peaks of the spine, preliminary studies indicate that patients who are subject to lengthenings at intervals of 6 months or less have a higher yearly growth rate $(1.8 \mathrm{~cm}$ vs. $1.0 \mathrm{~cm} ; \mathrm{P}=0.018)$, and a higher rate of definitive deformity correction $(79 \%$ versus $48 \%$; $P=0.007$ ) than patients in whom they were performed more frequently. ${ }^{12}$

The frequency of complications observed in the present study was within expectations, corroborating with literature $(23.3 \%$ to $\left.58 \%{ }^{15}\right) \cdot{ }^{14-18}$ The most frequent complications were related to instrumentation failure, particularly disconnections, loosening of the fixation points, and rod ruptures. These findings match the findings of a retrospective study carried out in 12 spine surgery units in Japan, which reported that implant failure accounted for $72 \%$ of the total complications recorded in patients with extension systems. ${ }^{28}$ This is similar to the frequency described by other groups. ${ }^{14-18}$

In this study, the only factor related to postoperative complications was the number of lengthenings performed. Similarly, a multicenter study carried out by the Growing Spine Study Group also recently described this relation; estimating a $24 \%$ increase in the risk of complications for every additional procedure performed. ${ }^{15,28}$ Based on these findings, it is advisable to delay the start of treatment, and minimize the frequency of the lengthenings as much as possible, in order to preserve the correction and the longitudinal growth of the spine.

Although the results of this study are quite similar to those reported in the literature, it is important to recognize several shortcomings of the study due to its retrospective design. For example, study sample does not strictly represent the total population attended during the described period, due to possible losses during some patient follow-ups (memory bias).

In addition, this study did not collect data on T1-S1 distances before and after each procedure, a difference that has been used in other studies as a secondary indicator of treatment effectiveness. ${ }^{22,25,29,30}$ Neither did it record the behavior of sagittal curves, although prior studies have shown that growing rods maintain, and may even improve these parameters. ${ }^{25,28}$

\section{CONCLUSION}

Treatment of scoliosis in patients under age 10 with growing rods has achieved a significant reduction in the magnitude of the deformity before final bone fusion. However, the rate of complications is rather high, and for this reason, we recommend reducing the frequency of lengthenings to a minimum, in order to maintain the correction and longitudinal growth of the spine.

All authors declare no potential conflict of interest related to this article.

CONTRIBUTION OF THE AUTHORS: Each author made significant individual contributions to this manuscript. CSM (0000-0001-9403-8947) and FA (0000-0002-8854-0356)* were the main contributors in the drafting of the manuscript. CSM, DM $(0000-0001-7814-6390)^{*}$, FA and WG (00000003-3802-5038)* reviewed the clinical charts to obtain data for the study. FA, GA (0000-0002-9705-3453)*, Carlos Martínez (falta Orcid) and RJM (0000-0001-9645-9446)* evaluated the data from the statistical analysis. GA, Carlos Martínez and RJM performed the literature search and review of the manuscript, and contributed to the intellectual concept of the study. *ORCID (Open Researcher and Contributor ID).

\section{REFERENCES}

1. Thompson GH, Akbarnia BA, Campbell RM Jr. Growing rod techniques in early-onset scoliosis. J Pediatr Orthop. 2007:27(3):354-61.

2. Akbarnia BA, Cheung K, Noordeen H, Elsebaie H, Yazici M, Dannawi Z, et al. Next generation of growth-sparing techniques: preliminary clinical results of a magnetically controlled growing rod in 14 patients with early-onset scoliosis. Spine (Phila Pa 1976). 2013:38(8):665-70.

3. Smith JR, Samdani AF, Pahys J, Ranade A, Asghar J, Cahill P, et al. The role of bracing, casting, and vertical expandable prosthetic titanium rib for the treatment of infantile idiopathic scoliosis: a single-institution experience with 31 consecutive patients. Clinical article. J Neurosurg Spine. 2009;11(1):3-8.

4. Samdani AF, Ranade A, Dolch HJ, Williams R, St Hilaire T, Cahill P, et al. Bilateral use of the vertical expandable prosthetic titanium rib attached to the pelvis: a novel treatment for scoliosis in the growing spine. J Neurosurg Spine. 2009;10(4):287-92.

5. Cheung KM, Cheung JP, Samartzis D, Mak KC, Wong YW, Cheung WY, et al. Magnetically controlled growing rods for severe spinal curvature in young children: a prospective case series. Lancet. 2012:379(9830):1967-74.

6. Yang JS, McElroy MJ, Akbarnia BA, Salari P, Oliveira D, Thompson GH, et al. Growing rods for spinal deformity: characterizing consensus and variation in current use. J Pediatr Orthop. 2010;30(3):264-70.

7. Yazici M, Olgun ZD. Growing rod concepts: state of the art. Eur Spine J. 2013;22 Suppl 2:S118-30
8. Moe JH, Kharrat K, Winter RB, Cummine JL. Harrington instrumentation without fusion plus external orthotic support for the treatment of difficult curvature problems in young children. Clin Orthop Relat Res. 1984;(185):35-45.

9. Yilmaz G, Huri G, Demirkran G, Dagloglu K, Ozkan C, Alanay A, et al. The effect of posterior distraction on vertebral growth in immature pigs: an experimental simulation of growing rod technique. Spine (Phila Pa 1976). 2010;35(7):730-3

10. Olgun ZD, Ahmadiadli H, Alanay A, Yazici M. Vertebral body growth during growing rod instrumentation: growth preservation or stimulation? J Pediatr Orthop 2012:32(2):184-9.

11. Akbarnia BA, Mundis GM Jr, Salari P, Yaszay B, Pawelek JB. Innovation in growing rod technique: a study of safety and efficacy of a magnetically controlled growing rod in a porcine model. Spine (Phila Pa 1976). 2012;37(13):1109-14.

12. Akbarnia BA, Breakwell LM, Marks DS, McCarthy RE, Thompson AG, Canale SK, et al. Dual growing rod technique followed for three to eleven years until final fusion: the effect of frequency of lengthening. Spine (Phila Pa 1976). 2008;33(9):984-90.

13. Caniklioglu M, Gokce A, Ozturkmen Y, Gokay NS, AticiY, Uzumcugil O. Clinical and radiological outcome of the growing rod technique in the management of scoliosis in young children. Acta Orthop Traumatol Turc. 2012;46(5):379-84.

14. Wang S, Zhang J, Qiu G, Wang Y, Li S, Zhao Y, et al. Dual growing rods technique for congenital scoliosis: more than 2 years outcomes: preliminary results of a single center. Spine (Phila Pa 1976). 2012;37(26):E1639-44.

15. Bess S, Akbarnia BA, Thompson GH, Sponseller PD, Shah SA, El Sebaie H, et al. Compli- 
cations of growing-rod treatment for early-onset scoliosis: analysis of one hundred and forty patients. J Bone Joint Surg Am. 2010;92(15):2533-43.

16. Faroog N, Garrido E, Altaf F, Dartnell J, Shah SA, Tucker SK, et al. Minimizing complications with single submuscular growing rods: a review of technique and results on 88 patients with minimum two-year follow-up. Spine (Phila Pa 1976). 2010;35(25):2252-8.

17. Wang W, Zhang JG, Qiu GX, Wang YP, Shen JX, Zhao Y, et al. [Analysis of clinical results and complications of growing rod technique for congenital scoliosis]. Zhonghua Wai Ke Za Zhi. 2013;51(9):821-6.

18. Yang JS, Sponseller PD, Thompson GH, Akbarnia BA, Emans JB, Yazici M, et al. Growing rod fractures: risk factors and opportunities for prevention. Spine (Phila Pa 1976). 2011;36(20):1639-44.

19. Mac-Thiong JM, Pinel-Giroux FM, de Guise JA, Labelle H. Comparison between constrained and non-constrained Cobb techniques for the assessment of thoracic kyphosis and lumbar lordosis. Eur Spine J. 2007:16(9):1325-31.

20. Steyerberg EW, Eijkemans MJ, Harrell FE Jr, Habbema JD. Prognostic modeling with logistic regression analysis: in search of a sensible strategy in small data sets. Med Decis Making. 2001:21(1):45-56

21. Li QY, Zhang JG, Qiu GX, Wang YP, Shen JX, Zhao Y, et al. Primary effect of dual growing rod technique for the treatment of severe scoliosis in young children. Chin Med J (Engl). 2010:123(2):151-5.

22. Akbarnia BA, Marks DS, Boachie-Adjei O, Thompson AG, Asher MA. Dual growing rod technique for the treatment of progressive early-onset scoliosis: a multicenter study. Spine (Phila Pa 1976). 2005:30(17 Suppl):S46-57.

23. Elsebai HB, Yazici M, Thompson GH, Emans JB, Skaggs DL, Crawford AH, et al. Safety and efficacy of growing rod technique for pediatric congenital spinal deformities. J Pediatr Orthop. 2011:31(1):1-5.

24. Zhao Y, Qiu GX, Wang YP, Zhang JG, Shen JX, Li SG, et al. Comparison of initial efficacy between single and dual growing rods in treatment of early onset scoliosis. Chin Med J (Engl). 2012:125(16):2862-6.

25. Sánchez-Márquez JM, Sánchez-Pérez-Grueso FJ, Fernández-Baillo N, García-Fernández A. Barras de crecimiento en escoliosis de inicio precoz ¿Permiten realmente el control de la deformidad y el crecimiento vertebral y torácico? Rev Esp Cir Ortop Traumatol. 2013;57(3):178-85

26. Cahill PJ, Marvil S, Cuddihy L, Schutt C, Idema J, Clements DH, et al. Autofusion in the immature spine treated with growing rods. Spine (Phila Pa 1976). 2010;35(22):E1199-203.

27. Flynn JM, Tomlinson LA, Pawelek J, Thompson GH, McCarthy R, Akbarnia BA. Growing-rod graduates: lessons learned from ninety-nine patients who completed lengthening. $J$ Bone Joint Surg Am. 2013;95(19):1745-50.

28. Watanabe K, Uno K, Suzuki T, Kawakami N, Tsuji T, Yanagida H, et al. Risk factors for complications associated with growing-rod surgery for early-onset scoliosis. Spine (Phila Pa 1976). 2013:38(8):E464-8.

29. Thompson GH, Akbarnia BA, Kostial P, Poe-Kochert C, Armstrong DG, Roh J, et al. Comparison of single and dual growing rod techniques followed through definitive surgery: a preliminary study. Spine (Phila Pa 1976). 2005;30(18):2039-44.

30. Schroerlucke SR, Akbarnia BA, Pawelek JB, Salari P, Mundis GM Jr, Yazici M, et al. How does thoracic kyphosis affect patient outcomes in growing rod surgery? Spine (Phila Pa 1976). 2012;37(15):1303-9. 